\title{
Organic Lawn Care Case Studies on Home Turf
}

\author{
Joseph R. Heckman ${ }^{1 *}$ \\ ${ }^{1}$ Department of Plant Biology, Rutgers University, New Brunswick, New Jersey, 08901, USA \\ * Joseph R. Heckman, E-mail: heckman@aesop.rutgers.edu
}

Received: November 2, 2016 Accepted: November 13, 2016 Online Published: December 27, 2016

doi:10.22158/ra.v2n1p1 URL: http://dx.doi.org/10.22158/ra.v2n1p1

\begin{abstract}
The consistent growth in certified organic farming and demand for organic foods has fostered a companion movement towards employing organic growing methods for land care. With the objective of evaluating the agronomic potential for organic land care, I conducted a case study on my property in Monroe, NJ following land disturbance from construction. After the site was remediated with deep tillage to alleviate compaction and amended with compost and limestone based on soil tests it was seeded in September 2009 with a mix of modern turf type Kentucky bluegrass cultivars. Once established, this lawn was attractive, competitive against most weeds, and performed well over the following six years under organic management. This lawn was mowed frequently with the clippings always returned so as to recycle nutrients in place. It remained attractive without fertilizer input. In 2014, another organic lawn study was established at my farm in Ringoes, NJ to evaluate several organic fertilizers. Observations from this second case study indicated that soil test $P$ was a key factor for turf establishment. Experience with the organic lawn in Ringoes, when contrasted to the results in Monroe, suggested that rapid germination and establishment of a dense turf stand is very important to preventing weeds during establishment.
\end{abstract}

\section{Keywords}

turf establishment, turf color, weeds

\section{Introduction}

The consistent growth in certified organic farming and demand for organic foods (USDA Agricultural Census, 2015) has fostered a companion movement towards employing organic growing methods for land care (Marshall, Orr, Bradley, \& Moorman, 2015). While the USDA National Organic Program (NOP) was developed for the certification of food and fiber products, the organic lawn care initiative is an independent program (Heckman, 2013). In 2001, The Northeast Organic Farming Association of Connecticut (NOFA Organic Land Care, n.d.) developed an accreditation program for organic land care professionals based on applying organic agricultural principles to landscaping. In 2014, Rutgers University developed an extension program in organic land care with standards modeled after those for 
organic crop production (Rutgers Organic Land Care, 2016).

Attempts to implement organic land care using conventional approaches to turf management have apparent ecological limitations (Heckman, 2006). Despite an appreciation that research is essential to place organic lawn care on a sound agronomic foundation, several attempts to garner funding for such research in New Jersey have been unsuccessful. In the absence of such funds, agronomists, much like pioneering organic farmers who lacked support from land grant universities or USDA (Lipson, 1997) can without outside funding use their own home lawns as case studies in organic lawn care. Although this home lawn approach may be criticized as lacking the academic rigor of fully funded experiments conducted at research centers, it nevertheless enables observations on how organic lawns actually function in the real world. This kind experience is at least a first step in the right direction. Furthermore, it enables this agronomist when invited to teach (Rutgers Organic Land Care, 2016) about organic lawn care to speak from practical experience and not just from assumptions and observations collected from conventional agricultural systems.

For the purpose of evaluating organic lawn care and the potential agronomic challenges, case studies were conducted on home lawns in Monroe and Ringoes, NJ.

\section{Materials and Methods}

In 2007 construction activity disturbed the landscape around my home property in Monroe, NJ. This site, with sandy loam soils, was used as the first case study for organic lawn care. The soils were degraded and severely compacted. In August 2009, the site was remediated with deep tillage using a back hoe to alleviate soil compaction in the surface 0 to $60 \mathrm{~cm}$. The surface $15 \mathrm{~cm}$ was amended with mushroom compost, applied as a $2 \mathrm{~cm}$ layer, and incorporated with a rototiller. Limestone was applied based on Rutgers Cooperative Extension soil tests recommendations. In September 2009, 0.01 ha of land area was seeded with a blend $16 \%$ each of cultivars of Kentucky bluegrass (Poa pratensis) cultivars (Midnight\#2, Freedom\#3, Bedazzled, NuDensity) and 16\% Zodiac Chewings Fescue (Festuca rubra subsp. Commutate), and 16\% Amazing GS Perennial Ryegrass (Lolium perenne). Once established, this lawn was mowed frequently (every 4 to 7 days) with the clippings always returned so as to recycle nutrients in place (Heckman, Liu, Hill, DeMillia, \& Anastasia, 2000). No fertilizer nutrients, beyond that which was added as mushroom compost and limestone in 2009, were ever applied over the six year period (2009 to 2015) of observation. This property was sold in April 2015, which effectively ended this case study for further observation.

In December 2013 our family moved to a farm in Ringoes, NJ. The existing farmhouse, constructed in 2001, was surrounded by a lawn in need of improvement. In August 2014, an area of 0.001 ha was designated for remediation and studies in organic lawn care. The study site was tilled to a depth of $20 \mathrm{~cm}$ using a rototiller to kill existing vegetation. In September 2014, the site was amended with $2 \mathrm{~cm}$ layer compost (made from yard waste and cow manure). Limestone was applied based on Rutgers Cooperative Extension soil tests recommendations. These amendments were incorporated with a rototiller. In 
mid-September the site was seeded with a one third blend each of cultivars P105 and Midnight\#1 Kentucky bluegrass and Falcon\#5 Tall Fescue (Festuca arundinacea). No fertilizer nutrients, beyond that which was added as compost and limestone in 2014, were applied until May 2015. On 2 May 2015, three different N-P-K organic fertilizer sources (Perdue Microstart 3N-0.9P-2.5K, Pelletized Poultry Feather Meal 7N-0.4P-0.8K, and Granular Poultry feather Meal 7N-0.9P-1.7K) were each applied at $96 \mathrm{~kg} \mathrm{~N} / \mathrm{ha}$ and compared to unfertilized control plots. These treatments were replicated 3 times in a randomized complete block design (individual plot size $=2 \mathrm{~m} \times 12 \mathrm{~m}$ ). The grass was mowed at least once per week and occasionally more often from May to September. Clippings were always left on the mowed lawn. Visual color quality was evaluated just prior to mowing and averaged for each month. A 1 to 10 scale was used with 1 representing brown turf and 10 representing dark green. Except during the period of establishment (fall 2014) the lawn was never irrigated in the 2015 season. August and September were unusually warm and dry months. In October 2015 the weed population was determined by counting the number of weeds in $0.5 \mathrm{~m}$ area of each plot. Analysis of Variance (ANOVA) was performed using the SAS GLM procedure (SAS Institute Inc. Cary, NC). A least squares means test $(\mathrm{P}<0.05)$ was used for the comparison of treatment means.

\section{Results and Discussion}

Once the lawn in Monroe was well established it became an attractive lawn. In early June 2013 (four years after establishment) the lawn was observed by a Rutgers Cooperative Extension County Agent who commented that this lawn under organic management looked "excellent". Because the turf was dense and healthy it was apparently very competitive against weeds and remained practically weed free for the six years of observation under organic management. Since the clippings were always returned, this effectively recycled most of the plant nutrients in place, and it offset the need to apply supplemental fertilizer.

This case study in Monroe suggests that a reasonably attractive lawn can be established and maintained over a period of several years under an organic system of management without intensive inputs. The organic lawn in Monroe, in contrast to surrounding unimproved lawn areas and in contrast to most neighboring conventional lawns, was consistently superior in appearance.

Creating favorable soil conditions is very likely an important first principle for establishing a successful organic lawn care program. Reseeding a lawn with modern turf type grass cultivars is another helpful practice.

In 2014, when an organic lawn study was established on the East side of our farmhouse in Ringoes, it afforded opportunity to make observations at a second location and in the spring 2015 to also collect turf color data in response to various organic fertilizer sources (Table 1).

This organic lawn in Ringoes, seeded to a blend of Kentucky bluegrass and tall fescue, was slower to establish than the organic lawn in Monroe. The turf stand was not as dense and was less competitive against weeds. Although the soil test P level was rated as optimum, P may have been limiting factor 
during the period of establishment. In contrast, the soil test $\mathrm{P}$ level was rated well above the optimum range for the study site in Monroe which established rapidly into a dense sward. Previous research (Hamel \& Heckman, 2006) has shown that turf establishment, or growth and density in the first seven weeks after seeding, is very responsive to level of available P. Thus, even with compost application at the Ringoes site, $\mathrm{P}$ availability may have been a limiting factor for establishment.

As a consequence of this slower to establish turf, the weed population, especially invasion from dandelion (Taraxacum officinale) and plantain (Plantago major), was much more of a problem at the Ringoes location. This observation suggests that agronomic practices permitted under organic systems should focus on encouraging rapid establishment for competiveness against weeds. Organic fertilizers capable of supplying readily available $\mathrm{P}$ should be investigated in this effort.

Turf color was improved with the applied organic fertilizers during the period May through July 2015 (Table 1). The feather meal fertilizers generally improve turf color more that the Microstart pelleted poultry litter. The feather meal products likely included some blood meal in the slaughter and processing waste which may account for some of the rapid green up associated with these products. In October 2015, the unfertilized plots had about 53\% more weeds than the fertilized plots (203 versus 132 weeds $\mathrm{m}^{2}$, respectively) but this trend did not reach the level of statistical significance $(P=0.29)$. Higher soil fertility levels are generally associated with weed suppression in turf (Heckman, Liu, Hill, DeMillia, \& Anastasia, 2000).

Table 1. Effect of Fertilizer Treatment on Turfgrass Color in 2015

\begin{tabular}{lllllll}
\hline \multicolumn{7}{c}{ Turfgrass Color Rating } \\
\hline & $\mathrm{N}$ & & & & & \\
Fertilizer & $(\mathrm{kg} / \mathrm{ha} / \mathrm{yr})$ & May & June & July & Aug. & Sept. \\
\hline Control & 0 & $4.7 \mathrm{c}^{*}$ & $3.7 \mathrm{c}$ & $4.3 \mathrm{~b}$ & $2.8 \mathrm{a}$ & $1.7 \mathrm{a}$ \\
Purdue Microstart 3N-0.9P-2.5K & 98 & $6.0 \mathrm{~b}$ & $5.3 \mathrm{~b}$ & $4.3 \mathrm{~b}$ & $2.3 \mathrm{a}$ & $1.7 \mathrm{a}$ \\
Poultry Feather Meal 7N-0.4P-0.8K & 98 & $6.0 \mathrm{~b}$ & $6.0 \mathrm{~b}$ & $5.0 \mathrm{a}$ & $2.3 \mathrm{a}$ & $2.7 \mathrm{a}$ \\
Poultry Feather Meal 7N-0.9P-1.7K & 98 & $8.0 \mathrm{a}$ & $8.0 \mathrm{a}$ & $5.7 \mathrm{a}$ & $2.3 \mathrm{a}$ & $1.7 \mathrm{a}$ \\
\hline
\end{tabular}

* Means within a column followed by different letters are significantly different at the $5 \%$ level according to Fisher's least significant difference test.

\section{Conclusion}

Experience with the organic lawn care at two different home sites provided valuable observations about the challenges of organic lawn care in the absence of research funds. At one site rapid establishment of a dense stand of grass from a new seeding appeared to be important to preventing the encroachment of weeds. But at second lawn site where a new lawn seeding was less vigorous, weed encroachment, especially by dandelion and plantain, was more serious. Nevertheless, even with the presence of these 
weeds, this organic lawn had good turf color and was attractive, especially when viewed from a distance. Depending on individual homeowner opinions, such an organic lawn may be considered acceptable to some people. More study years are needed to determine if lawns under organic management may improve or decline in turf density and competitiveness with weeds over time.

A survey of owners of home lawns should be conducted to determine if consumer preferences for organic products or systems may have different expectations for a lawn under organic management. Would, for example, organic minded consumers hold some appreciation for clover in lawns or some level of tolerance for the presence weeds? And is there a set of consumers that can be trained to accept a less than "perfect" lawn as a fair trade off for the avoidance of synthetic pesticide applications?

Experiences and observations gained from investigations on home turf can be a creative force to enable one to hypothesize on how to advance organic lawn care with future research once funding is secured. Future research should investigate how enhancing soil fertility during the critical period of establishment, might enhance competiveness against weeds.

An agronomist working first on their home lawn is novel approach to at least begin the research process in times of very limited research funds. Meanwhile it can also enable agronomists involved in teaching about organic lawn care to communicate with some authority based on direct experience.

\section{Acknowledgments}

We thank the Rutgers New Jersey Agricultural Experiment Station for performing the soil analysis. And thank you to Perdue AgriRecycle LLC for donation of organic fertilizer materials used in this research project.

\section{References}

Hamel, S. C., \& Heckman, J. R. (2006). Predicting Need for Phosphorus Fertilizer by Soil Testing During Seeding of Cool Season Grasses. HortScience, 41, 1690-1697.

Heckman, J. (2013). Organic Lawn Care. Retrieved May, 31, 2016, from https://www.njaes.rutgers.edu/pubs/soilprofile/sp-v21.pdf

Heckman, J. R. (2006). A History of Organic Farming: Transitions from Sir Albert Howard's War in the Soil to USDA National Organic Program. Renewable Agriculture and Food Systems, 21, 143-150. https://dx.doi.org/10.1079/RAF2005126

Heckman, J. R., Liu, H., Hill, W. J., DeMillia, M., \& Anastasia, W. L. (2000). Kentucky Bluegrass Responses to Mowing Practice and Nitrogen Fertility Management. Journal of Sustainable Agriculture, 15, 25-33. https://dx.doi.org/10.1300/J064v15n04_04

Lipson, M. (1997). Searching for the "O-Word”. Organic Farming Research Foundation, Santa Cruz, CA. $\begin{array}{llll}\text { Retrieved } \quad \text { May, } & 31, & \text { 2016, }\end{array}$ http://www.ofrf.org/sites/ofrf.org/files/docs/pdf/searching_for_o-word.pdf

Marshall, S., Orr, D., Bradley, L., \& Moorman, C. (2015). A review of organic lawn care practices and Published by SCHOLINK INC. 
policies in North America and the implications of lawn plant diversity and insect pest management. HortTechnolgy, 25, 437-446.

NOFA Organic Land Care. (n.d.). Retrieved May, 31, 2016, from http://www.organiclandcare.net/accreditation/standards

Rutgers Organic Land Care. (2016). Retrieved May, 31, 2016, from http://www.njaes.rutgers.edu/organiclandcare/

USDA Agricultural Census. (2015). Retrieved May, 31, 2016, from http://www.agcensus.usda.gov/Newsroom/2015/09_17_2015.php 